\title{
Mutagenesis in Plant Breeding for Disease and Pathogen Resistance
}

\author{
Aamir Raina and Mohammad Danish* \\ Department of Botany, Aligarh Muslim University, India
}

Submission: September 18, 2017; Published: January 08, 2018

"Corresponding author: Mohammad Danish, Department of Botany, Aligarh Muslim University, India, Email: danish.botanica@gmail.com

\begin{abstract}
Global food security faces several challenges such as erratic climate change, expanding human growth, depleted arable land and dwindling natural resources. The crop loss incurred by the infestation of pathogens and subsequent disease outbreaks has posed a serious threat to the food production across the globe. Induced mutagenesis is a promising technology to overcome the pest and disease outbreak in a wide array of economically important crops.
\end{abstract}

Keywords: Induced mutagenesis; Disease resistance

\section{Disease and Pest Resistance in Crop Plants}

Pathogens affect almost all cash crops and cause a significant reduction in overall yield. In addition to the pathogen frequent disease outbreaks in wide array of crop plants remains serious challenge and pose threats to overall food security causing global yield loss of about 16\% [1]. Actual losses incurred by pathogens range from $26-29 \%$ for sugar beet, barley, soybean, wheat and cotton, to $31-40 \%$ for maize, potato and rice [1]. Plant parasitic nematodes also play a critical role in decreasing the global crop productivity with a resultant global cost of $>\$ 120$ billion p.a. [2]. Agriculture intensification, poor agronomic practices such as implementation of monoculture, use of chemical fertilizer and inconsistent irrigation are the main factors that led to disease outbreak and decrease in crop yield. Management of pathogens and diseases need to be given due consideration and different methods to combat the crop losses have been developed. Intriguing evidence suggest that the induced mutagenesis is a promising and viable approach to develop resistant cultivars. Using induced mutagenesis, traits for disease and pest resistance have been improved in cereals, legumes and other important crops.

\section{Induced Mutagenesis}

The term mutagenesis refers to the artificial induction of random or site directed mutations in plants to create new valuable traits in otherwise outstanding crops. Both physical mutagens such as ionising radiations and chemical mutagens such as alkylating agents are utilised for the development of elite crop varieties. Radiation usually causes large chromosomal aberration and chemical mutagens cause point mutations [3-6]. Induced mutagenesis has been used to create plant varieties that show resistance to pathogen and disease outbreak. The main mutagenic crops improved for disease resistance are rice, barley, maize, wheat, bean, green pea. Recently in 2017, Niab Kinnow mutant variety of Citrus reticulata has been developed from budwoods of local Kinnow irradiated at 20 Gy of gamma rays. This variety has shown moderate to high resistance to Citrus canker, scab and wither-tip diseases as well as low incidence to major insect pests. Similarly in 2004, Wonchu mutant variety of Oryza sativa has been developed by irradiating seeds at $250 \mathrm{~Gy}$ of gamma rays. This variety has been to shown to have higher yield and better disease resistance.

\section{Recommendation}

One of the main goals of future agriculture is to attain durable and broad-spectrum resistance to disease and pathogens. Mutagenesis enables the identification of wild genes or the creation of novel genes that impart disease resistance. Induced mutagenesis offers many benefits to agriculture, especially when there is no reliable source of resistance found in the nature that makes it impossible to introduce to susceptible cultivars by hybridization. Understanding defence responses offer the possibility to introduce new combinations of alleles from wild varieties into modern crop. 


\section{References}

1. Oerke EC (2006) Crop losses to pests. J Agric Sci 144: 31-43.

2. Karuri HW, Olago D, Neilson R, Njeri E, Opere A, et al. (2017) Plant parasitic nematode assemblages associated with sweet potato in Kenya and their relationship with environmental variables. Tropical Plant Pathol 42(1): 1-12.

3. Raina A, Laskar RA, Khursheed S, Amin R, Tantray YR, et al. (2016) Role of mutation breeding in crop improvement-past, present and future. Asian Res J Agr 2: 1-13.
4. Raina A, Laskar RA, Khursheed S, Khan S, Parveen K, et al. (2017) Induce Physical and Chemical Mutagenesis for Improvement of Yield Attributing Traits and their Correlation Analysis in Chickpea. International Letters of Natural Sciences 61: 14-22.

5. Khursheed S, Raina A, Parveen K, Khan S (2017) Induced phenotypic diversity in the mutagenized populations of faba bean using physical and chemical mutagenesis. J Saudi Society Agric Sci.

6. FAO/IAEA (2017) Database of Mutant Variety and Genetic Stocks.

\section{Your next submission with Juniper Publishers will reach you the below assets}

- Quality Editorial service

- Swift Peer Review

- Reprints availability

- E-prints Service

- Manuscript Podcast for convenient understanding

- Global attainment for your research

- Manuscript accessibility in different formats

(Pdf, E-pub, Full Text, Audio)

- Unceasing customer service

Track the below URL for one-step submission https://juniperpublishers.com/online-submission.php 